\title{
Abuses and Penalties of a Corporate Tax Inversion
}

\author{
James G. S. Yang *, Leonard J. Lauricella and Frank J. Aquilino \\ Department of Accounting \& Finance Montclair, Montclair State University, Montclair, NJ 07043, USA; \\ lauricellal@montclair.edu (L.J.L.); aquilinof@montclair.edu (F.J.A.) \\ * Correspondence: yangg@mail.montclair.edu
}

Received: 26 October 2018; Accepted: 8 January 2019; Published: 13 January 2019

\begin{abstract}
There is a serious problem in international taxation today. Many United States (U.S.) multinational corporations have moved abroad to take advantage of a lower tax rate in a foreign country. As a consequence, the tax base in the U.S. has been seriously eroded. This practice is known as "corporate tax inversion". This paper discusses the abuses and penalties of this phenomenon. It is rooted in some deficiencies in the U.S. tax law. This paper points out that the U.S. has the highest corporate tax rate in the world. It imposes tax on worldwide income. It permits deferral of tax on foreign-sourced income until dividends are repatriated back to the U.S. As a result, it creates tax loopholes. This paper reveals six actual cases of corporate tax inversion. This practice has triggered the Congress to enact \$7874, the Internal Revenue Service (IRS) to issue Notices IR 2014-52 and IR 2015-79, and the U.S. Treasury Department to promulgate TD 9761. This paper investigates some details of these penalties. This paper further demonstrates an example in determining the amount of tax savings by engaging in a corporate tax inversion. It also offers many strategies.
\end{abstract}

Keywords: corporate inversion; controlled foreign corporation; international taxation; U.S.-sourced income; foreign-sourced income; merger; worldwide income; territorial income

JEL Classification: $\mathrm{H} 26$

\section{Introduction}

In the arena of international taxation, there is an earth-shaking crisis going on in the U.S. today. Many U.S. multinational corporations are moving abroad resulting in an erosion of the tax base in the U.S. The detriments to the U.S. treasury are astronomical and devastating. Worse yet, it is happening only in the U.S., not in other countries. This strategy is known as a "corporate tax inversion".

What is a corporate tax inversion? Why is it so popular nowadays? What are the purposes behind this rather disastrous tax practice? This paper will point out the fundamental deficiencies in the U.S. tax law that causes this epidemic. It will reveal the real intention for a U.S. multinational corporation to engage in such a tax strategy. This paper will also investigate the history of corporate tax inversion. In addition, it will demonstrate an example to show how to determine the amount of income tax that a corporate tax inversion strategy can expect to save. Further, this paper will also scrutinize the recent U.S. Treasury Department actions on the Internal Revenue Code (IRC) §7874 and the Internal Revenue Service (IRS) Notices 2014-52 and 2015-79, and TD 9761 against the abuse of corporate tax inversion. These aspects sustain the substance of this paper.

\section{Benefits of a Corporate Inversion}

Without a doubt, a U.S. multinational corporation earns income not only from within the U.S. itself but also from many other foreign countries. Similarly, a foreign corporation may also derive income from within both its own host country but also from within the U.S. If these two different 
corporations are combined, it raises the question as to how these two different sources of income are taxed. The problem becomes more complicated because it concerns two different corporations in two different countries. The solution will touch on many elements, such as tax rate, taxable base, tax authority, taxing entity, etc. Maneuvering among these aspects is the basis of a corporate inversion.

\subsection{Changing the Tax Rate}

The maximum corporate federal tax rate in the U.S. was 35\% before 1 January 2018. This is the highest tax rate among developed countries. The lowest tax rate is $12.5 \%$ in Ireland. In between, the tax rate is $34.4 \%$ in France, 34\% in Brazil, 25\% in China, 19\% in the United Kingdom, and 15\% in Canada, among others (Fairless and Raice 2014). In another extreme, the tax rate in many tax haven countries is even zero $(0 \%)$ such as the Bahamas, Bermuda, the Cayman Islands, and the British Virgin Islands.

The differences in tax rates indicate that a shift of income from the U.S. to Bermuda, as an example, can save as much as 35\% (35\%-0\%). A shift of income to Ireland can save $22.5 \%$ (35\%-12.5\%). Even a shift of income from the U.S. to Canada can save as much as $20 \%(35 \%-15 \%)$.

The strategy of a corporate inversion is to shift income from one country to the other. The difference in tax rates between two countries certainly motivates a U.S. multinational corporation to seek tax shelter with a lower tax rate in another country.

\subsection{Changing the Taxable Income}

On the one hand, a U.S. multinational corporation invariably derives income not only from U.S. sources, but also from abroad. However, both are eventually taxable in the U.S. This is known as "worldwide income tax" ((IRC, §862(a)(2)). On the other hand, other foreign governments impose tax only on their domestic-sourced income, but not the foreign-sourced income. This is termed "territorial income tax". This indicates that the foreign-sourced income is tax-free in a foreign country". It leads to the result that a corporation in a foreign country may be treated more favorably than its counterpart in the U.S. This treatment creates unfair competition.

For instance, if a U.S. corporation earns income from Ireland, it is taxable in the U.S. In contrast, if an Irish corporation earns income from the U.S., it would not be taxable in Ireland. The amount of difference in tax liability can be quite significant because of the globalization of business today. The U.S. and the Irish corporations definitely derive income from each other's country of incorporation.

The difference in taxable income is certainly one of the incentives that motivate a U.S. multinational corporation to move abroad. A corporate inversion provides a technique to accomplish this purpose.

\subsection{Changing the Taxing Authority}

If a U.S. multinational corporation has income from a foreign country, who has the taxing authority-the U.S. government or a foreign government? The tax rates are, more often than not, different between these two countries. For example, Burger King is a U.S. corporation, but it also earns income from Canada. How should it be taxed? It depends on Burger King's tax domicile. If it is the U.S., the tax rate was 35\%; whereas, if it is Canada, the tax rate is $15 \%$.

How to change the tax rate? If Burger King simply renounces its corporate U.S. citizenship and moves its tax domicile to Canada, the income from Canada is no longer subject to the taxing authority of the U.S. government. Instead, the Canadian income now belongs to the authority of the Canadian government. Better yet, if the Canadian tax rate is lower than that of the U.S., the difference in tax liability creates tax savings. If Burger King in Canada now still derives income from the U.S., and the Canadian government does not impose tax on foreign-sourced income, the U.S.-sourced income would be tax-free in Canada, though the U.S. government still imposes its own tax. This is precisely the benefit of a corporate inversion.

In other words, Burger King's Canada-sourced income has an opportunity to be taxed at only $15 \%$ in Canada by means of a corporate inversion. In contrast, Burger King's U.S.-sourced income 
has no such an opportunity. It can only be taxed in the U.S. at 35\%. In that sense, Burger King's Canada-sourced income is more flexible and maybe more beneficial than its U.S.-sourced income.

\subsection{Changing the Taxing Entity}

A U.S. parent corporation may own a controlled foreign corporation (CFC) in a foreign country. The earnings from the CFC are generally not taxable in the U.S., unless the earnings are distributed as dividends to the U.S. parent corporation. The taxing entity is still the U.S. parent corporation. How can the taxing entity be changed?

The U.S. parent corporation may change its tax domicile from the U.S. to any foreign country. If it does so, it is no longer a U.S.-registered corporation, but a foreign corporation registered in a foreign country. Any earnings distributed from the old CFC to this new foreign corporation are no longer subject to the U.S. taxation, because the new foreign corporation is not a U.S. corporation. The taxing entity has been changed from a U.S. corporation to a non-U.S. corporation. This is another use of a corporate inversion.

This strategy shows that the taxing entity of foreign-sourced income is changeable. It can change the status of income from taxable to nontaxable. A corporate inversion is the vehicle to carry out this mission.

\subsection{Changing the Source of Income}

The strategy of a corporate inversion offers still another advantage. A U.S. multinational corporation may have U.S.-sourced income as well as foreign-sourced income. The former is immediately taxable in the U.S.; whereas, the latter is not taxable in the U.S. until the dividends are repatriated back to the U.S. (IRC, §862(a)(2)). Evidently, the latter is more preferable than the former. Can income be changed from a U.S.-sourced income to a foreign-sourced income? The answer is affirmative. How is it accomplished?

For example, K-mart sold merchandise from the U.S. to customers in China. The profit is immediately taxable in the U.S. If K-mart sets up a controlled foreign corporation in China and makes it purchase the same merchandise from the same supplier and sell it to the same customer in China, the income is treated as foreign-sourced income and not taxable in the U.S. until the dividends are distributed to the U.S. The strategy of a corporate inversion has changed the seller from the U.S. to China. As a result, it has also changed the same amount of income from the U.S.-sourced income to foreign-sourced income.

Again, only an international transaction can render such a benefit; a U.S. domestic transaction cannot. All these benefits may explain why a corporate inversion has become so popular nowadays. There can certainly be more advantages.

In the next section it would be interesting to know how a corporate inversion actually works. More importantly, how much tax savings can it really derive? It would be useful to demonstrate an example. It will involve two different corporations operating in two different countries. If they merge what is the total tax liability. It concerns the aspect of foreign tax credit. If the same income is taxed in two different countries, the U.S. allows a foreign tax credit to the extent of the tax liability attributable to the foreign-sourced income (IRC, $\$ 904(a)$ ). The subject will become more complicated, as will be illustrated below.

\section{Example for a Corporate Inversion}

U.S. Corporation has $\$ 60,000,000$ U.S.-sourced income and $\$ 40,000,000$ Irish-sourced income. Irish Corporation has $\$ 20,000,000$ U.S.-sourced income and $\$ 80,000,000$ Irish-sourced income. The U.S. adopts the "worldwide income tax" policy at a rate of $35 \%$. Ireland adopts the "territorial income tax" policy at a rate of $12 \%$. What is the total tax liability for these two corporations together without and with a corporation inversion, respectively? What is the amount of tax savings by engaging in a corporate inversion in this scenario? All data and results are summarized in Table 1 below. 
Table 1. Tax without and with inversion.

\begin{tabular}{cccc}
\hline & Income & Tax without Inversion & Tax with Inversion \\
\hline U.S. Corporation: & & & \\
\hline (a) U.S. Source & $\$ 60,000,000$ & $21,000,000(35 \%)(\mathrm{a})$ & $21,000,000(35 \%)(\mathrm{e})$ \\
(b) Irish Source & $40,000,000$ & $14,000,000(35 \%)(\mathrm{b})$ & $4,800,000(12 \%)(\mathrm{f})$ \\
Irish Corporation: & & & \\
\hline (c) U.S. Source & $\$ 20,000,000$ & $7,000,000(35 \%)(\mathrm{c})$ & $7,000,000(35 \%)(\mathrm{g})$ \\
(d) Irish Source & $80,000,000$ & $9,600,000(12 \%)(\mathrm{d})$ & $9,600,000(12 \%)(\mathrm{h})$ \\
Total & $200,000,000$ & $51,600,000$ & $42,400,000$ \\
\hline
\end{tabular}

\subsection{Without Corporate Inversion}

(a). Without a corporate inversion, the U.S. Corporation pays $\$ 21,000,000(\$ 60,000 \times 35 \%)$ tax to the U.S. government for its $\$ 60,000,000$ U.S.-sourced income.

(b). Without a corporate inversion, the U.S. Corporation pays $\$ 4,800,000(\$ 40,000,000 \times 12 \%)$ tax to the Irish government for its $\$ 40,000,000$ Irish-sourced income. Since the U.S. government adopts the "worldwide income tax policy", the U.S. Corporation must pay $\$ 14,000,000(\$ 40,000,000 \times 35 \%)$ tax to the U.S. government for its $\$ 40,000,000$ Irish-sourced income. However, the U.S. Corporation can claim the $\$ 4,800,000$ tax paid to the Irish government as a "foreign tax credit" against the $\$ 14,000,000$ tax liability to the U.S. government, resulting in a net tax payment of $\$ 9,200,000(\$ 14,000,000-4,800,000)$. The total tax payment for the U.S. Corporation is still $\$ 14,000,000(\$ 9,200,000+4,800,000)$ for the $\$ 40,000,000$ Irish-sourced income.

(c). Without a corporate inversion, the Irish Corporation pays nothing to the Irish government for its $\$ 20,000,000$ U.S.-sourced income, because the Irish government adopts the "territorial income tax policy". However, the Irish Corporation must pay $\$ 7,000,000(\$ 20,000,000 \times 35 \%)$ tax to the U.S. government for its $\$ 20,000,000$ U.S.-sourced income.

(d). Without a corporate inversion, the Irish Corporation pays $\$ 9,600,000(\$ 80,000,000 \times 12 \%)$ tax to the Irish government for its $\$ 80,000,000$ Irish-sourced income. However, the Irish Corporation pays no tax to the U.S. government, because it is not U.S.-sourced income.

The total tax payment for these two corporations together without a corporate inversion is $\$ 51,6000,000(\$ 21,000,000+14,000,000+7,000,000+9,600,000)$.

\subsection{With Corporate Inversion}

(e). With a corporate inversion, the combined corporation pays $\$ 21,000,000(\$ 60,000,000 \times 35 \%)$ to the U.S. government for its $\$ 60,000,000$ U.S.-sourced income under the old U.S. Corporation.

(f). With a corporate inversion, the combined corporation pays $\$ 4,800,000(\$ 40,000,000 \times 12 \%)$ tax to the Irish government for its $\$ 40,000,000$ Irish-sourced income under the old U.S. corporation.

(g). With a corporate inversion, the combined corporation pays $\$ 7,000,000(\$ 20,000,000 \times 35 \%)$ to the U.S. government for its $\$ 20,000,000$ U.S.-source income under the old Irish Corporation.

(h). With a corporate inversion, the combined corporation pays $\$ 9,600,000(\$ 80,000,000 \times 12 \%)$ tax to the Irish government for its $\$ 80,000,000$ Irish-sourced income under the old Irish Corporation.

The total tax payment for these two corporations together with a corporation inversion is $\$ 42,400,000(\$ 21,000,000+4,800,000+7,000,000+9,600,000)$.

\subsection{Tax Savings by Corporate Inversion}

The difference in total tax payment between without and with a corporate inversion is $\$ 9,200,000$ $(\$ 51,600,000-42,400,000)$ in favor of a corporate inversion. That is the amount of tax savings by engaging a merger between U.S. Corporation and Irish Corporation and moving its tax domicile from the U.S. to Ireland. It exactly comes from the $\$ 40,000,000$ Irish-sourced income under the old U.S. Corporation. It was taxed at $35 \%$ without a corporate conversion because of the U.S. government's "worldwide income tax policy". However, it is now taxed at only $12 \%$ after a corporate inversion 
because of the Irish government's "territorial income tax policy". The difference in tax rates is $23 \%$ $(35 \%-12 \%)$ and the amount of tax savings is $\$ 9,200,000$, i.e., $\$ 40,000,000 \times 23 \%$.

This example points out one important principle. The U.S. Corporation may have both U.S.-sourced income and Irish-sourced income. Similarly, the Irish Corporation may also have U.S.-sourced income and Irish-sourced income. Not all these four categories of income can save income tax. Any U.S.-sourced income is always taxed at a U.S. tax rate of $35 \%$. There is no tax savings opportunity. The Irish Corporation's Irish-source income cannot save income tax either because it is not subject to the U.S. taxation. Only the U.S. Corporation's Irish-sourced income can give rise to tax savings. This category of income was subject to the U.S. taxation without a corporate inversion, but it is beyond the jurisdiction of the U.S. government with a corporate inversion. In this sense the true tax savings by a corporate inversion may be limited. Any taxpayer contemplating a corporate inversion must be aware of the source of tax savings.

\section{Objectives of a Corporate Inversion}

In fact, the phenomenon of corporate inversion is not new. It started three decades ago in 1982. Only after 1994 did it become more popular. By 2014, according the Congressional report, 76 corporations had inverted causing $\$ 19.5$ billion of loss in tax revenue (The U.S. House of Representatives Ways and Means Committee 2014). In the last decade alone forty-seven were inverted (The U.S. House of Representatives Ways and Means Committee 2014). In 2012 and 2013, 20 have followed suit (Fairless and Raice 2014). In 201410 inverted. In 2015 six have done so as well (Raice and Mattioli 2015). The most recent case on 23 November 2015 was an announced merger between Pfizer and Allergan (Merced 2015), though on 5 April 2016 it was abruptly cancelled (de la Merced and Picker 2016).

The trend seems to be accelerating. Why has it become so rampant today? More importantly, what has motivated the movement? By investigating many of the actual cases of corporate inversion in the past history, two objectives appear to be paramount. The first objective is to avoid the U.S. taxation on foreign earnings. The second objective is to avoid the high U.S. corporate tax rate for the foreign-sourced earnings repatriated to the U.S., as will be elaborated below.

\subsection{Avoiding Tax on the Distribution of Foreign Earnings}

As noted above, in the past long history, the U.S. tax law adopts the so-called "worldwide income" tax policy, while a great majority of other industrialized countries employs the "territorial income" tax policy. The former imposes tax on both the U.S.-sourced income and the foreign-sourced income, but it allows a corporation to defer the tax liability on the undistributed foreign-sourced income. On the other hand, the latter imposes tax only on the domestic-sourced income, but not the foreign-sourced income. In other words, in many other countries, the foreign-sourced income is tax-free. Obviously, there is a disparity between the U.S. and a foreign country.

That discrepancy causes unfair competition between the U.S. multinational corporations and other foreign corporations. In order to reduce the U.S. tax liability many U.S. multinational corporations made strenuous efforts to generate foreign-sourced income and also shun dividends distributions from earnings of a controlled foreign corporation. As a result of these efforts, by 2014, the U.S. multinational corporations had accumulated a huge amount of untaxed earnings in many foreign countries. It amounts to $\$ 2$ trillion that causes a loss of $\$ 20$ billion in tax revenue (Schoen 2014).

From the viewpoint of these U.S. multinational corporations there is a burning desire to distribute these foreign earnings without triggering the U.S. taxation. This was actually the first objective of corporate inversion in its early years.

McDermott Case: In as early as 1982 McDermott, Inc. was a U.S.-registered corporation in Louisiana in the construction business. It also earned income from Panama. If the Panamanian subsidiary corporation distributed dividends to its parent corporation of McDermott, Inc., it would have triggered U.S. corporate taxation at the McDermott, Inc. level. In order to avoid the corporate tax, 
McDermott, Inc. sets up McDermott, International, as a Panama-registered corporation in Panama. McDermott, International, issued stock to the shareholders of the old McDermott, Inc. in exchange for their stock and also to the old Panamanian subsidiary corporation. McDermott, International, became the parent corporation of the old McDermott, Inc. and the old Panamanian subsidiary corporation. The parent-subsidiary relationship between the old McDermott, Inc. and the new McDermott, International, was thus flipped around.

Now the old Panamanian subsidiary corporation can distribute dividends to McDermott, International. It is hence not taxable in the U.S., because the new McDermott, International, is not a U.S. corporation. Nevertheless, the dividends received by the shareholders of McDermott, International, is still taxable in the U.S., but these dividends would have been taxed to U.S. shareholders under the pre-inversion set-up anyway.

This was known to be the first case of corporate inversion. The main purpose was to be able to distribute the future earnings of a controlled foreign corporation without paying U.S. tax at the corporate parent level.

Helen of Troy Case: There was a similar case in 1993. Helen of Troy was a U.S.-registered corporation in Texas in the cosmetic business. It owned many subsidiary corporations in many foreign countries. Again, if these foreign subsidiary corporations distributed dividends to the parent company of Helen of Troy in the U.S., it would trigger U.S. taxation at the Helen of Troy corporate level. In order to escape it, Helen of Troy set up a corporation in Bermuda. As in the case of McDermott, the new Bermuda corporation issued stock to the shareholders of the old Helen of Troy in exchange of their stock and to all other Helen of Troy's CFCs. The new Bermuda corporation became the parent corporation of both the old Helen of Troy and all other CFCs. Those CFCs can distribute dividends to this new Bermuda corporation. It would not be taxable in the U.S., because the new Bermuda corporation is not a U.S. corporation. Better yet, Bermuda is a tax shelter country where there is no income tax at all. The new Bermuda corporation can transfer these distributed dividends to Helen of Troy. As a result, Helen of Troy can now use the earnings from all CFCs without paying the U.S. tax. It has accomplished the same objective as the case of McDermott, Inc. This case further demonstrates the usefulness of a corporate inversion.

The above two cases occurred in the early stages of the corporate inversion technique. The real purpose was not so much to take advantage of a lower tax rate in a foreign country, but rather the avoidance of the entire U.S. corporate taxation on the distribution of earnings from a controlled foreign corporation. In the next section, this paper will point out the cases where the primary purpose was to avoid the U.S. taxation on the foreign-sourced income. In fact, the most corporate inversion cases in recent years belong to this situation.

\subsection{Avoiding Tax on Foreign-Sourced Income}

During past decade many European countries cut their tax rates. For example, Ireland reduced its tax rate to as low as $12.5 \%$, and Canada to $15 \%$. It motivated the U.S. multinational corporations to take advantage of the tax rates that were lower than the U.S. If a U.S. corporation's foreign-sourced income is taxed in the U.S. at as high as 35\%, the best strategy is to move the corporation's tax domicile to a lower-tax foreign country. This is the real purpose of a corporate inversion. The following prominent and shocking cases substantiate this intention. They are Burger King, Medtronic, and Pfizer.

Burger King Case: In as recently as 2014 Burger King was a U.S.-registered corporation in the fast-food restaurant chain business around the world. It earned income from Canada that was taxed in the U.S. at a rate of $35 \%$. It sounds unfair. Tim Hortons was a Canada-registered corporation in the same line of business in Canada. Burger King and Tim Hortons are almost equal in size.

They have now merged to become Restaurant Brands, International, with headquarters in Canada. They became a giant in their field of business with $\$ 23$ billion in sales revenue a year from 18,000 restaurants in 100 countries serving 11 million customers a day (Hoffman and Mattioli 2014). The profit and its associated tax liability are gigantic. 
Unfortunately, from the viewpoint of the U.S. government, Burger King has moved its tax domicile from the U.S. to Canada. The U.S. government thus lost its tax authority over Burger King. Although the portion of income from within the U.S. is still subject to taxation in the U.S., the income from foreign countries is no longer taxed in the U.S. The amount of loss in tax revenue is tremendous. The portion of income from Canada is still taxed in Canada, but the tax savings amount to up to $20 \%$ (35\%-15\%) (McKinnon and Paletta 2014).

The motive of the Burger King case is not so much the tax-free distribution of earnings from a controlled foreign corporation. Burger King did not own Tim Hortons in the first place. Instead, it is the ill-effect of imposing the U.S. tax on Burger King's income from Canada that motivated Burger King to move. This is the consequence of a corporate inversion.

Medtronic Case: In as late as 2015 Medtronic was a U.S.-registered corporation specializing in the research and production of medical devices, such as pacemakers. It sold its products around the world through many foreign subsidiary corporations. It had accumulated as much as $\$ 13$ billion of untaxed profits still sitting overseas (Laryer 2016). If these funds were distributed back to Medtronic headquarters in the U.S. they would be taxed at a rate of $35 \%$.

It should be noted that the medical research efforts need a great amount of funds and the U.S. is still the best medical incubator in the world. Medtronic could not afford to leave the research facilities in the U.S. Ireland offers a tax at as low as $12.5 \%$. Medtronic was merged into Convidien in Ireland to become a new Medtronic as an Ireland-registered corporation. Both are pharmaceutical firms. Medtronic moved its tax domicile from the U.S. to Ireland, but it continues to operate in the U.S. as usual. Now the new Medtronic in Ireland can send funds to the old Medtronic in the U.S. to engage in medical research without triggering the U.S. taxation.

The Medtronic case shoots two birds with one stone. It saves the U.S. tax on both fronts: the foreign-sourced income and the undistributed earnings from controlled foreign corporations. The strategy of corporate inversion is indeed multifaceted.

Pfizer Case: Most recently on 23 November 2015 an earth-shaking merger was announced. Pfizer in the U.S. is to acquire Allergan in Ireland for a whopping price of $\$ 150$ billion that will create one of the biggest pharmaceutical firms in the world with $\$ 300$ billion in market share (Hoffman et al. 2015). This will be so far the biggest merger in history. Pfizer will move its tax domicile from the U.S. to Ireland. The motive is the same as the Medtronic case. Pfizer has accumulated $\$ 74$ billion of untaxed profits overseas (Rubin 2015). If Pfizer distributes these profits back to the U.S. it will trigger a vast amount of tax liability. The strategy of a corporate inversion can avoid it. A corporate inversion can also avoid the U.S. tax liability on its foreign-sourced income. It will yield tax savings of $\$ 2$ billion a year (Hoffman et al. 2015).

The above five cases are only a tiny portion of corporation inversion. In fact, there are seventy-six (76) cases in total. Other notable cases include Tyco International to Bermuda, Aon to the United Kingdom, Noble to Switzerland, Ensco to the United Kingdom, Perrigo to Ireland, Omnicom to the Netherlands, Chiquita to Ireland, Ingersoll to Bermuda, Fruit of the Loom to the Cayman Islands, etc. (Bloomberg 2014).

All these cases are pursuing the same objectives: distributing foreign earnings without paying U.S. corporate level tax and reducing tax on foreign-sourced income. Are they legal? Ironically, the answer is affirmative. It is the deficiencies of the U.S. tax law that is to blame. It is now the government's turn to fix it. In the next section this paper will scrutinize the new tax regulations that attempt to curtail the abuse.

\section{Penalties of a Corporate Inversion}

The tax law has many rules. Violation of the tax rule is subject to a penalty. Imposition of tax is a form of such a penalty. The abuse of corporation inversion became more rampant only in the last decade. At that time, the maximum corporate tax rate was as high as $35 \%$. Therefore, the boundary of such a tax penalty was set at that level. 
In the arena of international taxation, corporate mergers and acquisitions with foreign entities are normal and ordinary business operations that promote economic efficiency. Unfortunately, in the past decade the strategy has been abused to become a tax avoidance scheme. It has caught the attention of the U.S. Treasury Department. Since then Congress enacted IRC \$7874 (The IRC n.d., §7874) in 2004 and the Internal Revenue Service issued Notice IR 2014-52 (The IRS 2014) in 2014 and Notice IR 2015-79 (The IRS 2015) in 2015, the U.S. Treasury Department promulgated regulations TD 9761 (The U.S. Treasury 2016) in 2016. They all are intended to impose penalties on those who abuse the tax law. The new regulations concern the tax on undistributed foreign earnings, size of the new combined foreign corporation, and the post-inversion intercompany loans.

This section investigates what international transactions that constitute such an abuse of the tax law. It also scrutinizes how a multinational corporation intentionally creates such a transaction. More importantly, it further describes what efforts the U.S. government has taken in an attempt to curtail the abuses by imposing tax penalties.

\subsection{Capital Gain on the Exchange of Stocks in an Inversion Transaction}

The best strategy of a corporate inversion is to create a foreign corporation in a foreign country which in turn issues stock to the shareholders of the old U.S. parent corporation in exchange for its stock. Should the gain on the exchange be taxable on the part of the shareholders? The answer was negative because stock is not property. It happened in the McDermott case in 1982. The same situation happened again in the case of Helen of Troy in 1993. At that time, it caught the attention of the Treasury Department which in turn issued new regulations that make it taxable under the authority of $\$ 367(\mathrm{~b})$ (The IRC n.d., §367(b)). That was the first action by the U.S. government.

The above two cases demonstrate that, in an ordinary transaction, the exchange of two stocks should not result in taxable income. However, if this transaction is intended for corporation inversion, it will. As such, it is taxed at a maximum rate of $35 \%$. That is a tax penalty. It also shows the government's efforts to prevent the abuse of corporation inversion.

\subsection{Distribution of Untaxed Foreign Earnings by Means of an Inversion}

Actually, in larger part, the strategy of corporate inversion involves the taxation on earnings of a foreign subsidiary. To what extent should the foreign-sourced income be taxed in the U.S.? Can there be any abuse? If so, it is subject to a tax penalty.

In an ordinary relationship, the U.S. parent corporation owns an old controlled foreign corporation (CFC). Any dividend distribution from the old CFC to the U.S. parent corporation would be taxable in the U.S. There is one way to avoid it. The U.S. parent corporation may create a new CFC which in turn issues stock to the U.S. parent corporation and also to the old CFC. The new CFC becomes the parent corporation of the U.S. parent corporation and the old CFC. The old CFC now can distribute dividends to the new CFC. The distribution is not taxable in the U.S. because the new CFC is not a U.S. corporation.

Code $\$ 7874(\mathrm{c})(2)(\mathrm{A})$ provides that, if the scheme is intended to avoid U.S. taxation, the issuance of the said stock is deemed void for tax purposes (The IRC n.d., \$7874(c)(2)(A)). It does not count. The U.S. parent corporation still owns the old CFC. Any dividend distribution from the old CFC to the new CFC is treated as a distribution from the old CFC to the U.S. parent corporation and thus taxable in the U.S. This is a tax penalty.

In another situation, if the new CFC utilizes the funds from the old CFC to purchase stock or property from the U.S. parent corporation, it is treated as a dividend distribution from the old CFC to the U.S. parent corporation, and it is hence taxable in the U.S. as well (The IRC n.d., §7874(c)(2)(A)). This is another tax penalty.

The strategies for corporate inversion have become more sophisticated in recent years. In response, the government's regulations have also become more complicated. As a result, the scope of tax penalty has also become much broader as well. For example, a distribution of a CFC's earnings to the U.S. 
parent corporation is supposed to be a taxable income. An attempt may be may be made to create a new CFC and then distribute the old CFC's earnings to the new CFC. It bypasses the U.S. parent corporation and hence this distribution would be tax-free in the U.S. This is the strategy described above. It can be termed as "earnings bailout". Unfortunately, it is now treated as a taxable income subject to a tax penalty at $35 \%$.

These new regulations attempt to prevent diversion of the taxable earnings to a nontaxable entity. There are more.

\subsection{The New Foreign Corporation as a U.S. Domestic Corporation Due to an Inversion}

A corporate inversion invariably involves the combination of a domestic corporation and a foreign counterpart. It is better known as a merger. After the merger, should the merged entity still be treated as a domestic corporation? It gives rise to the question of tax liability of a taxing entity.

IRC $\$ 7874$ concerns the ownership of the new foreign corporation. It is true that the status as a foreign corporation is treated more favorably than a U.S. domestic corporation, as mentioned before. After the inversion, if the combined new foreign corporation still has at least $25 \%$ of its business volume from the foreign country of incorporation, it is indeed treated as a "foreign corporation", per se. None of its earnings are taxable in the U.S. Under the IRS Notice 2015-79 Section 2.02(a), to be qualified as a "foreign corporation", it must also be a tax resident of that foreign country of incorporation (The IRS 2015, The IRS Notice IR 2015-79 Section 2.02(a)).

If the U.S. shareholders own at least $60 \%$, but less than $80 \%$, of the stock, it is treated as a "surrogate foreign corporation" where only the earnings in proportion to its ownership percentage is taxable in the U.S.

On the other hand, if the U.S. shareholders own at least $80 \%$ of the stock, the combined new foreign corporation shall be treated as a "U.S. domestic corporation" (The IRC n.d., §7874(b)), where it is subject to worldwide income tax. Its entire amount of earnings is taxable in the U.S. It completely denies the benefits of a corporate inversion.

These new tax rules determine how much of the income after the corporate inversion is taxable in the U.S. Since the tax rate in the U.S. is always higher than that of other countries in the world, the U.S.-sourced income results in a greater amount tax liability than that of the foreign-sourced counterpart. This is another form of tax penalty in choosing different source of income. It is rather ironic to observe that the U.S.-sourced income is less advantageous than that of the foreign-sourced counterpart. For example, the tax rate in Ireland is as low as $12.5 \%$, as compared to $35 \%$ in the U.S. If a corporation inversion ends up with being treated as a U.S.-sourced income, the tax disadvantage is as great as $22.5 \%(35 \%-12.5 \%)$. It explains why the corporation inversion is still thriving in favor of the outbound direction, meaning moving from the U.S. to other countries. This is another penalty of a corporate inversion. This $80 \%$ ownership criterion is extremely important. It determines the tax status of the combined new foreign corporation. A taxpayer should make every effort to avoid it. Therefore, under the new regulations, the size of ownership of the combined new corporation becomes a major concern, as will further be elaborated below.

\subsection{Determining the Ownership of the New Foreign Corporation after the Inversion}

There is another corporate inversion strategy that may lead to tax penalties. It involves the manipulation of sizes of the U.S. parent corporation and a foreign corporation. More often than not, the strategy may become quite vicious.

As mentioned above, the $80 \%$ ownership is a red-line not to cross over. The U.S. parent may intentionally make an effort to circumvent it. There can be many strategies. For example, it may distribute a rather large amount of dividends to the U.S. shareholders before the inversion. On one side of the equation, this action will shrink its assets value. As a result, it will reduce the relative size of ownership of the U.S. shareholders in the new foreign parent corporation. The IRS Notice 2014-52, 
Section 2.02(b) renders it void (The IRS 2014, the IRS Notice 2014-52 Section 2.01(2)). This is a tax penalty of a corporate inversion.

The foreign corporation may also intentionally inject a huge amount of nonessential assets, such as cash, marketable securities or passive assets. On the other side of the equation, the action will boost the assets value of the foreign corporation. As a result, it will also reduce the relative size of the ownership of the U.S. shareholders. This action like others is intentional to circumvent the percentage tests. The IRS Notice IR 2014-52, Section 2.01(2) made it invalid (The IRS 2014, IRS Notice IR 2014-52, Section 2.01(2)). These kinds of assets are called "nonqualified assets". Under the IRS Notice IR 2015-79 Section 3.03(a), the "nonqualified assets" are expanded to include all assets, not just cash, marketable assets and passive assets (The IRS 2015, the IRS Notice IR 2015-79 Section 3.03(a)). This is another tax penalty.

There may be another strategy. In addition to a foreign corporation, a U.S. parent corporation may create another foreign corporation. Now, all three corporations are merged together. This strategy will certainly reduce the size of the U.S. shareholders. As such, it avoids the size test. The IRS Notice IR 2015-79 Section 2.02(b) provides that the third corporation is ignored in determining the size (The IRS 2015, IRS Notice IR 2015-79 Section 2.02(b)).

There is still another strategy involving the manipulation of the size of a foreign corporation. Just before the merger the foreign corporation may intentionally issue more stock to foreign shareholders. This action will have the effect of reducing the relative ownership percentage of the U.S. shareholders. The purpose is to avoid the percentage test. The U.S. Treasury regulation TD 9761 Explanation to Provision Section I(B)(5)(a) provides that any stock issued three years before the merger does not count in determining the size of the combined corporation (The U.S. Treasury 2016, U.S. Treasury Department Regulations, TD 9761 Explanation to Provision Section I(B)(5)(a)).

In other words, the above strategies do not count in determining the relative ownership of the U.S. shareholders. This is a tax penalty. These are other penalties on corporate inversion under the new tax regulations. There are still more abuses and penalties, as will be investigated below.

\subsection{Intercompany Loans Subsequent to an Inversion}

There is still another strategy to distribute the earnings of a CFC to the U.S. parent corporation without paying the U.S. tax. Before the inversion, if a CFC makes an intercompany loan to the U.S. parent corporation, under Section 956 the amount of loan is treated as a dividend distribution from a CFC to the U.S. parent corporation and thus taxable in the U.S. After the inversion this old CFC may no longer be the U.S. parent corporation's CFC. If the above mentioned intercompany loan happens again, it will still be treated as a taxable income in the U.S. (The IRC n.d., §956). This is a tax penalty of a corporation inversion.

Later, when the U.S. parent corporation pays interest to the CFC, it is otherwise treated as interest expense on the part of the U.S. parent corporation and reduces its taxable income. The interest received by the CFC is otherwise treated as in income and thus increases its taxable income. This amount of interest has actually shifted the U.S. parent corporation's taxable income to the CFC. Better yet, the CFC's income is not taxable in the U.S.

If this is the intention of income shifting, the IRS Notice IR 2014-52 Section 3.02(a) renders it void again (The IRS 2014, IRS Notice IR 2014-52 Section 3.02(a)). Interest expense is not deductible on the part of the U.S. parent corporation. Similarly, interest income is not taxable on the part of the CFC. Worse yet, under U.S. Treasury Department Regulations TD 9761 Explanation to Provision Section II(B)(1)(a), this kind of intercompany loan is treated as "equity", rather than a debt instrument (The U.S. Treasury 2016, U.S. Treasury Department Regulations TD 9761 Explanation to Provision Section II(B)(1)(a)). As such, any payment from the U.S. corporation to a CFC is treated as "dividends distribution" that reduces equity, instead of "interest expense" that decreases net income (The U.S. Treasury 2016, U.S. Treasury Department Regulations TD 9761 Explanation to Provision Section II(B)(1)(a)). 
This is yet another penalty of a corporate inversion. There can be more. These restrictions are intended to discourage the use of corporate inversion. Those taxpayers who have a legitimate reason to use a corporate merger are encouraged to do so. However, those who attempt to abuse it shall face stiff penalties.

\section{Conclusions}

This paper deals with the problems of a quite tumultuous subject today-corporate inversion. It reveals many abuses and penalties that are associated with it. This paper points out that a U.S. multinational corporation may derive income from not only the U.S. itself, but also from many foreign countries. Unfortunately, the tax treatments are quite different between them. The income from the U.S. is taxable immediately, but the income from a foreign country is not taxable until cash dividends are received. The tax rate in the U.S. is much higher than that of a foreign country. Further, the taxing authority of the U.S.-sourced income is always the U.S. government, while the foreign-sourced income may be a foreign government. In addition, the taxing entity of the U.S.-sourced income is always the U.S. multinational corporation; whereas, the taxing entity of the foreign-sourced income many be a foreign corporation. This paper explores all of these differences. It points out that the disparities between the U.S. and a foreign country give rise to a corporate inversion.

This paper cites many actual cases of a corporate inversion. It illustrates that each case has different purpose. This paper also demonstrates one example to show how to determine the amount of tax savings by using a corporate inversion.

Furthermore, this paper points out that the technique of corporate has become so abusive today that it has triggered Congress to enact $\$ 7874$ and the Internal Revenue Service to issue Notices 2014-52 and 2015-79, and the U.S. Treasury Department to promulgate TD 9761. All of them attempt to impose many restrictions on the use of a corporate inversion. This paper investigates some details. It concerns the size of a combined corporation, the distribution of untaxed earnings from a controlled foreign corporation, the intercompany loan, etc. This paper also explains the reasons for these restrictions.

Finally, this paper offers a note of precaution. The technique of a corporate inversion is highly popular today in the arena of international taxation. It can indeed derive a great deal of tax benefits. Unfortunately, it has caught the attention of the U.S. Treasury Department. Many more restrictions are about to be issued in the very near future. Any taxpayer who attempts to take advantage of the loopholes in the U.S. tax law must be aware of the possible consequences and pitfalls.

Author Contributions: Conceptualization: J.G.S.Y., L.J.L., and F.J.A.

Funding: This research received no external funding.

Conflicts of Interest: The authors declare no conflict of interest.

\section{References}

Bloomberg. 2014. Tracking Tax Runaways: Bloomberg Inversion Database. Available online: http:// www.bloomberg.com/infographics/2014-09-18/tax-runaways-tracking-inversions.html (accessed on 13 January 2019).

de la Merced, Michael, and Leslie Picker. 2016. Pfizer and Allergan Said to End Merger as Tax Rules Tighten. The New York Times, April 6, B1.

Fairless, Tom, and Shayindi Raice. 2014. Firms Drawn to U.K. for Tax Deals. The Wall Street Journal, July 29, C3.

Hoffman, Liz, and Dana Mattioli. 2014. Berger King in talks on Canada Tax Deal. The Wall Street Journal, August 25, A1.

Hoffman, Liz, Richard Rubin, and Jonathan D. Rockoff. 2015. Taxes Drive Drug Merger. The Wall Street Journal, October 30, A1.

Laryer, Brittney. 2016. Medtronic to Buy Hear-Care Firm. The Wall Street Journal, June 27, B3.

McKinnon, John D., and Damian Paletta. 2014. Burger King-Tim Hortons Plan Raises Tax-Inversion Issue. The Wall Street Journal, August 26, B4. 
Merced, Michael J. 2015. Pfizer Reaches Takeover Deal with Allergan. The New York Times, November 23, A1.

Raice, Shayndi, and Dana Mattioli. 2015. Inversion Deals Retain Their Allure. The Wall Street Journal, August 7, B2. Rubin, Richard. 2015. Pfizer Piles Profits Abroad. The Wall Street Journal, November 9, B1.

Schoen, John. 2014. Corporate Inversions are the Latest Ploy to Upend the U.S. Tax Code. Available online: https:/ / www.cnbc.com/2014/07/24/ corporate-inversions-are-the-latest-ploy-to-upend-the-ustax-code.html (accessed on 22 September 2014).

The IRC. n.d. The Internal Revenue Code; New York: The IRC.

The IRS (The Internal Revenue Service). 2014. IRS Notice 2014-52 Rules Regarding Inversion and Related Transactions; Washington, DC: The IRS.

The IRS (The Internal Revenue Service). 2015. IRS Notice 2015-79 Additional Rules Regarding Inversion and Related Transactions; Washington, DC: The IRS.

The U.S. House of Representatives Ways and Means Committee. 2014. Congressional Research Service report on "New CRS Data: 47 Corporate Inversions in Last Decade; Washington, DC: The U.S. House of Representatives.

The U.S. Treasury. 2016. Inversion and Related Transactions; TD 9761; Washington, DC: The U.S. Treasury.

(C) 2019 by the authors. Licensee MDPI, Basel, Switzerland. This article is an open access article distributed under the terms and conditions of the Creative Commons Attribution (CC BY) license (http:/ / creativecommons.org/licenses/by/4.0/). 